\title{
Homocysteine, vitamins-B and atherosclerotic disease
}

\author{
A.R. Inge Permadhi
}

\begin{abstract}
Abstrak
Homosistein termasuk dalam kelompok asam amino bersulfur yang akan mengalami dua jalur metabolisme utama yaitu melalui jalur transulfurasi menjadi sistein dan melalui remetilasi menjadi metionin. Homosistein merupakan faktor risiko independen terhadap terjadinya penyakit pembuluh-darah dini. karena dapat menyebabkan perlukaan sel endothelial pembuluh darah. Hal tersebut terjadi karena homosistein dapat bersifat vaskulotoksik dan thrombogenik. Penyebab dari hiperhomosisteinemia ini multifaktorial. Namun demikian, secara umum hiperhomosisteinemia disebabkan oleh terhambatnya salah satu atau kedua jalur metabolisme homosistein. akibat defisiensi koenzim yang dibutuhkan dalam metabolisme homosistein, yaitu vitamin $B_{60} B_{12}$, dan asam folat. Keadaan hiperhomosisteinemia ini dapat diperbaiki melalui suplementasi ketiga vitamin tersebut.
\end{abstract}

\begin{abstract}
Homocysteine is a sulfur containing amino acid metabolized either through transulfuration to cysteine via cystathionine or through remethylation to methionine. Homocysteine is now known as an independent risk factor for premature vascular disease due to its vasculotoxic and thrombogenic property. The etiology of hyperhomocysteinemia is multifactorial, but generally is caused by inhibition of one or both pathways, due to coenzyme(s) deficiency. These coenzymes are required for its metabolism, ie. vitamin $B_{6}, B_{I 2}$, and folic acid. Hyperhomocysteinemia can be effectively recovered by supplementation of those three vitamins.
\end{abstract}

Keywords: vitamin $B_{6}$ (pyridoxine), $B_{12}$ (cobalamin), folate (folic acid), atherosclerosis.

The known risk factors of atherosclerosis, ie. hypertension, hyperlipidaemia and smoking have been extensively socialized. However, recently, another independent risk factor was identified, i.e. homocysteine which was considered as a potential risk factor for the development of atherosclerotic diseases.

In untreated atheroslerotic disease due to hyperhomocysteinemia, the affected individuals will develop large atherosclerotic lessions as well as thromboembolic events early in life, and often die before the age of 30 due to stroke or myocardial infarction.

Homocysteine is a non proteinogenic amino acid. It is an intermediate formed during the metabolism of the essential sulfur-containing amino acid methionine, and not taken from the diet. In human plasma, homocysteine exists in different forms, including the major protein-bound fraction $(65 \%)$, free oxidized

Nutrition Study Programme, Postgraduate programme, University of Indonesia, Jakarta, Indonesia fraction (30\%) where cysteine-homocysteine mixed disulphide predominates, and trace amounts (1.5-4\%) of reduced homocysteine. ${ }^{2}$

This paper provides an overview of homocysteine metabolism, factors influencing homocysteine metabolism, the etiology, classification and treatment of hyperhomocysteinemia, the role of vitamin B in recovering the altered homocysteine metabolism to reduce the risk of atherosclerosis, and the pathophysiology of atherosclerosis due to hyperhomocysteinemia.

\section{HOMOCYSTEINE METABOLISM}

Homocysteine metabolism pathway (Figure 1) consists of two separate metabolic pathways, i.e. the transulfuration and remethylation. Homocysteine is either converted to cystathionine and then cystein by transulfuration, or remethylated to methionine.

In the remethylation pathway, 5-Methyltetrahydrofolate-homocysteine methyltransferase (methionine synthase) is widely distributed and requires N5- 
Figure 1. Homocysteine metabolism ${ }^{1,3,4}$

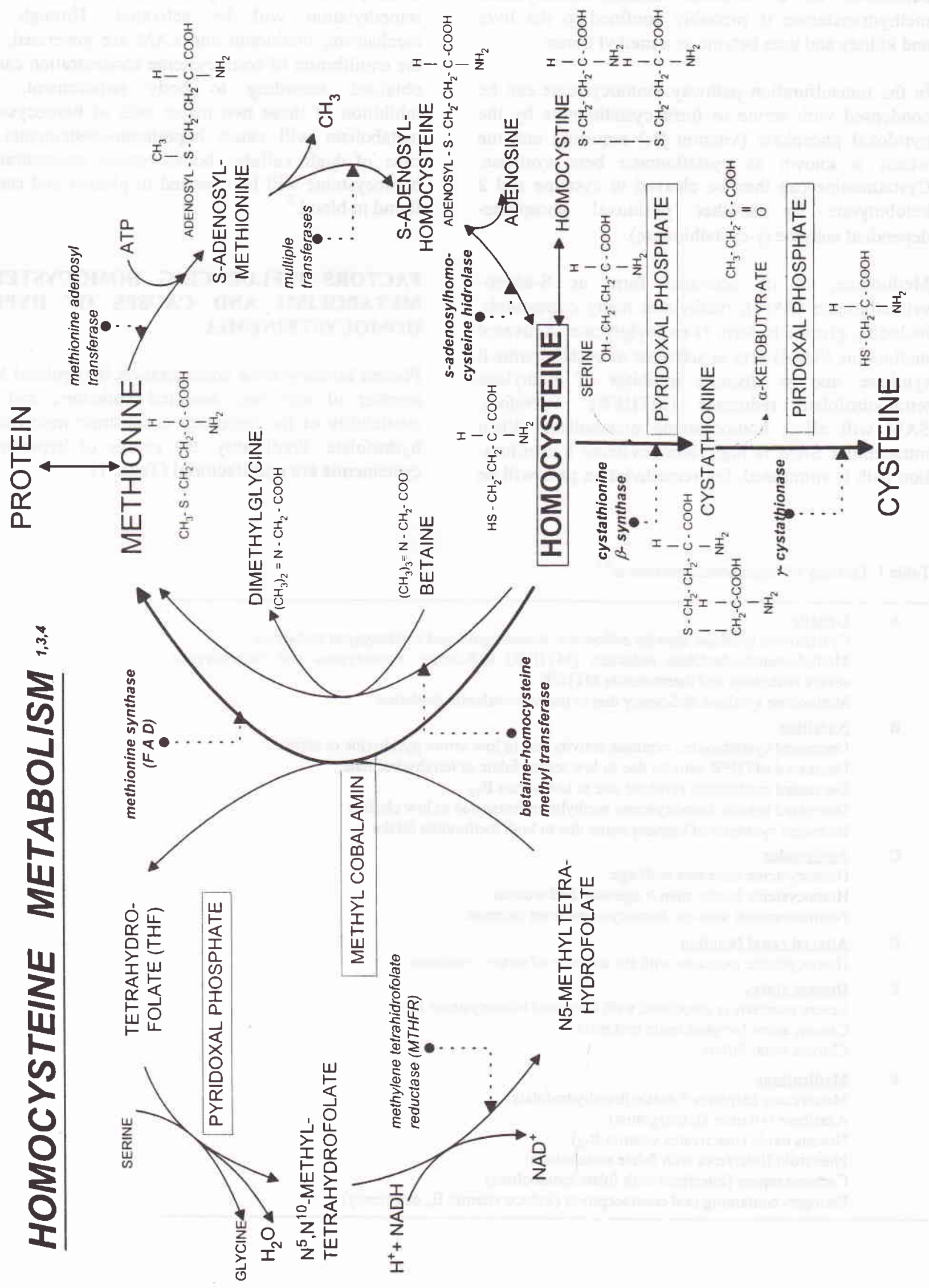


methyltetrahydrofolate as a methyl donor and methyl cobalamin as a cofactor. Betaine-homocysteine methyltransferase is probably confined to the liver and kidney and uses betaine as a methyl donor.

In the transulfuration pathway, homocysteine can be condensed with serine to form cystathionine by the pyridoxal phosphate (vitamin $\mathrm{B}_{6}$ ) requiring enzyme which is known as cystathionine beta synthase. Cystathionine can then be cleaved to cysteine and 2 ketobutyrate by another pyridoxal phosphatedependent enzyme ( $\gamma$-cystathionase).

Methionine, in its activated form as S-adenosylmethionine (SAM), methylates many compounds, including glycine to form $\mathrm{N}$-methylglycine. Activated methionine (SAM) acts as activator of cystathionine $\beta$ synthase, and as alosteric inhibitor of methylene tetrahydrofolate reductase (MTHFR). Therefore, SAM will affect homocysteine metabolism. When intracellular SAM is high, homocysteine transulfuration path is stimulated, but remethylation path will be supressed. On the other hand, when SAM concentration is low, transulfuration path will be supressed, and remethylation will be activated. Through this mechanism, methionin and SAM are generated, and the equilibrium of homocysteine concentration can be obtained according to body requirement. The inhibition of these two major path of homocysteine metabolism will cause hyperhomo-cysteinemia. In case of high cellular homocysteine concentration, homocysteine will be expelled to plasma and can be found in blood. ${ }^{5}$

\section{FACTORS INFLUENCING HOMOCYSTEINE METABOLISM AND CAUSES OF HYPER- HOMOCYSTEINEMIA}

Plasma homocysteine concentration is regulated by a number of enzymes, essential cofactors, and the availability of the important cosubstrate methylteriahydrofolate. Predictably, the causes of hyperhomocysteinemia are multifactorial (Table 1).

Table 1. Etiology of hyperhomocysteinemia ${ }^{6,7}$

\section{A Genetic}

Cystationine synthase activity deficiency: homozygous and heterozygous mutations

Methylentetrahydrofolate reductase (MTHFR) deficiency: homozygous and heterozygous severe mutations and thermolabile MTHFR.

Methionine synthase deficiency due to methylcobalamin depletion

\section{B Nutrition}

Decreased cystathionine synthase activity due to low serum pyridoxine or serine

Decreased MTHFR activity due to low serum folate or tetrahydrofolate

Decreased methionine synthase due to low serum $B_{12}$

Decreased betaine-homocysteine methyltransferase due to low choline

Increased synthesis of homocysteine due to high methionine intake

\section{Age/gender}

Homocysteine increases with age

Homocysteine levels: men > age-matched women

Postmenopausal women: homocysteine level increase

D Altered renal function

Homocysteine increases with the increase of serum creatinine

E Disease states

Severe psoriasis is associated with increased homocysteine level

Cancer, acute lymphoblastic leukemia

Chronic renal failure

\section{F Medications}

Metotrexate (depletes 5-methyltetrahydrofolate)

Azaribine (vitamin $B_{6}$ antagonist)

Nitrous oxide (inactivates vitamin $\mathbf{B}_{12}$ )

Phenytoin (interferes with folate metabolism)

Carbamazepine (interferes with folate metabolism)

Estrogen-containing oral contraceptives (induce vitamin $\mathrm{B}_{6}$ deficiency) 


\section{Genetic}

Homozygotes for classical homocystinuria have low or undetectable activity of cystathionine $\beta$-synthase and a characteristic excessively elevated plasma homocysteine. Another genetic defect is inherited remethylation cycle abnormalities including derangement of methionine synthase caused by disorders of cobalamin metabolism. ${ }^{8}$

\section{Nutrition}

Homocysteine levels can be significantly elevated in deficiencies of the essential cofactors i.e. vitamin $B_{6}$, and $\mathrm{B}_{12}$, or deficiency of the cosubstrate (folate).

\section{Age}

Ubbink, et al ${ }^{9}$ investigated white and black children aged 7-15 years old in South Africa. They found that average plasma homocysteine concentration of white and black children were $5.1 \pm 0.9 \mu \mathrm{mol} / \mathrm{L}$ and $5.8 \pm 1.8$ $\mu \mathrm{mol} / \mathrm{L}$ respectively. Several studies also found that homocysteine concentration increased with age. ${ }^{1,9}$ In healthy adults of middle age, the homocysteine blood concentration was $10-15 \mu \mathrm{mol} / \mathrm{L}$ and elderly person showed homocysteine concentration of about 10-25 $\mu \mathrm{mol} / \mathrm{L} .{ }^{\prime}$ The reasons of the increment of plasma homocysteine concentration with age are the decrease in cofactor level, or coexisting renal impairment often seen in older patients. Furthermore, age dependent reductions in cystathionine $\beta$-synthase may also play a part. $^{7}$

\section{Gender}

In general, men have higher plasma homocysteine level than women. Homocysteine concentration increases in both genders with age. After menopause, fasting homocysteine concentration may increase. Although gender differences in homocysteine concentration may be explained by the effect of sex hormones on homocysteine metabolism, they may be related to higher creatinine value, or the greater muscle mass in men compared to women. ${ }^{7}$

\section{Renal function}

There is a positive correlation between fasting plasma homocysteine and serum creatinine, although the mechanism is unclear. In chronic renal failure, plasma homocysteine level may be two to four times higher than normal. This concentration will decrease after dialysis, or will decrease $30-60 \%$ after oral folate supplementation of $5-10 \mathrm{mg} / \mathrm{day} .^{10}$ In renal failure, increase in homocysteine results from impaired metabolism rather than excretion. ${ }^{11}$

\section{Disease states}

Severe psoriasis is associated with elevated fasting plasma homocysteine level, possibly related to lower folate level. ${ }^{12}$ Markedly elevated homocysteine level was seen in acute lymphoblastic leukemia, and homocysteine level decreased after treatment with cytotoxic drugs. ${ }^{13}$ Moderately elevated homocysteine concentration was also seen in patients with various carcinomas, including breast, ovarian and pancreatic carcinomas, who had highly elevated tumor markers. Methionine metabolism may be altered in malignant cells. Plasma level may be related to the large burden of proliferating cells unable to utilize endogenous homocysteine. ${ }^{14}$

\section{Drugs}

Plasma homocysteine level may also be influenced by pharmacologic agents. Methotrexate depletes 5methyltetrahidrofolate, the cosubstrate for methionine synthase. Nitrous oxide inactivates vitamin $\mathbf{B}_{12}$ dependent methionine synthase. ${ }^{15}$ Anticonvulsants, such as phenytoin and carbamazepine, interfere folate metabolism, and may also increase homocysteine concentrations. ${ }^{12}$ Azaribine, intialy used for refractory cases of psoriasis, is a vitamin $\mathrm{B}_{6}$ antagonist and inhibits cystathionine $\beta$-synthase. ${ }^{12}$ Estrogen-containing oral contraceptives may alter the metabolism of sulfur containing amino acids, including homocysteine. Although women taking oral contraceptives usualy have reduced plasma homocysteine, high levels may be seen in some. ${ }^{14}$

\section{CLASSIFICATION OF HYPERHOMOCYSTEINEMIA}

The normal level of homocysteine concentration have not been defined due to the different results of some investigations. ${ }^{1}$ Stabler et al ${ }^{11}$ determine $7-22 \mu \mathrm{mol} / \mathrm{L}$, while $\mathrm{Kang}^{6}<16 \mu \mathrm{mol} / \mathrm{L}$ as normal homocysteine concentration respectively. Table 2 shows the classification of hyperhomocysteinemia. 
Table 2. Classification of hyperhomọcysteinemia ${ }^{6}$

\begin{tabular}{|c|c|c|}
\hline $\begin{array}{l}\text { Classification of } \\
\text { hyperhomo- } \\
\text { cysteinemia }\end{array}$ & $\begin{array}{c}\text { Plasma } \\
\text { homocysteine } \\
(\mu \mathrm{mol} / \mathrm{L})\end{array}$ & Etiology \\
\hline Severe form & $>100$ & $\begin{array}{l}\text { - Cystathionine syntase } \\
\text { deficiency } \\
\text { - MTHFR deficiency } \\
\text { - Nutritional inadequacy } \\
\text { with or without minor } \\
\text { genetic defect }\end{array}$ \\
\hline $\begin{array}{l}\text { Intermediate } \\
\text { form }\end{array}$ & $31-100$ & $\begin{array}{l}\text { - Methionine synthase } \\
\text { deficienicy due to defect } \\
\text { in cobalamin metabolism } \\
\text { - Compound hetero- } \\
\text { zygosity of MTHFR } \\
\text { - Interallelic combination } \\
\text { of genetic defects } \\
\text { - Nutritional inadequacy } \\
\text { with or without genetic } \\
\text { defect }\end{array}$ \\
\hline Moderate form & $16-30$ & $\begin{array}{l}\text { - Interallelic } \\
\text { combination of minor } \\
\text { genetic defects } \\
\text { - Nutritional inadequacy } \\
\text { with or without genetic } \\
\text { defect }\end{array}$ \\
\hline
\end{tabular}

\section{TREATMENT OF HYPERHOMOCYSTEINEMIA}

Treatment of hyperhomocysteinemia is summarized in Table 3. For the correction of genetic defect, two conditions are required to activate alternative pathway or to enhance the activity of the mutant enzyme. In the first condition, the presence of material used in alternative pathway is essential. In the second condition, cofactor supplementation is required for the activity of the mutant enzyme. For instance, pyridoxal phosphate (the cofactor of cystathionine $\beta$-synthase) can be used to activate mutant cystathionine $\beta$ synthase. In this case, about $50 \%$ of mutant cystathionine $\beta$-synthase is activated by supplementation of pyridoxal phosphate (100-1000 mg/day). If the mutant enzyme cannot be activated by the supplementation of its cofactor or the precursor of its cofactor, the amplification of an alternative pathway(s) should be considered for the efficient turnover of homocysteine. ${ }^{6}$

Hyperhomocysteinemia caused by homozygous defects in MTHFR indicate that betaine supplement may be suitable method of treatment. Pharmacological doses of betaine facilitate homocysteine remethylation by betain-homocysteine methyltransferase. ${ }^{6} \mathrm{~A}$ single genetic defect, such as heterozygous cystathionine $\beta$ synthase deficiency, may be insufficient to produce consistent hyperhomocysteinemia without the involvement of nongenetic factor(s). Therefore, the maintenance of serum concentrations of folate, $B_{12}$ and $\mathrm{B}_{6}$ above normal limits may be adequate for the treatment. $^{6}$

Table 3. Treatment of hyperhomocysteinemia ${ }^{6}$

\begin{tabular}{ll}
\hline A Genetic hyperhomocysteinemia \\
Activation of mutant enzyme: pyridoxine-responding \\
cystathionine synthase by pyridoxine. \\
Increase of substrate concentration in: thermolabile \\
MTHFR by supplementation of folic acid \\
Reduction of homocysteine turnover: supplementation \\
of folic acid, choline and betaine \\
B Nutritional hyperhomocysteinemia \\
Correction of nutritional inadequacy: supplementation \\
of folic acid, vitamin $B_{12}$, pyridoxine, choline, and betaine.
\end{tabular}

Ubbink et al found the effect of vitamins i.e. folate, $\mathrm{B}_{12}$ and $\mathrm{B}_{6}$, as homocysteine lowering agents. ${ }^{16}$ Study on men with moderate hyperhomocysteinemia $(>16.3$ $\mu \mathrm{mol} / \mathrm{L}$ ), in 6 weeks trial using supplementation of either folic acid $(0.65 \mathrm{mg} /$ day), pyridoxine (10 $\mathrm{mg} /$ day), cyanocobalamin $(0.4 \mathrm{~g} /$ day $)$ or the combination of these vitamins, showed that pyridoxine had no homocysteine lowering effect, whereas vitamin $\mathrm{B}_{12}$ decreased plasma homocysteine by a mean of $15 \%$. Most but not all responded to folate, with the mean homocysteine concentration decrease of $42 \%$. In contrast, all responded to the combination, showing a mean homocysteine reduction of $50 \%$. In men, the reduction obtained by supplementing folate alone did not differ significantly from the effect obtained by giving a combination of folate, vitamin $\mathrm{B}_{12}$ and vitamin $\mathrm{B}_{6}$.

Hyperhomocysteinemia due to vitamin $\mathrm{B}_{12}$ deficiency does not respond to folate therapy. It is likely, that even in subjects with low normal vitamin $B_{12}$ concentrations full respond to folate cannot be achieved unless vitamin $B_{12}$ is given concomitantly. In this case, for several reasons, folate seems to reduce almost all homocysteine levels, including low homocysteine level. Furthermore, cyanocobalamin will probably secure full folate responsiveness. ${ }^{17} \mathrm{On}$ the other hand, there are recent data that suggest that folate alone are sufficient for homocysteine reduction. However, the combinated supplementation will be an innocuous means that not only normalizes homo- 
cysteine concentration, but also will normalize vitamin concentrations and optimize the folate effect. ${ }^{17}$

Hyperhomocysteinemia caused by deficiencies of vitamin $B_{6}, B_{12}$ and folate can be treated by the combined supplementation of folate, vitamin $\mathrm{B}_{12}$ and $\mathrm{B}_{6}$ given daily in an amount of 2.5-4 times the recommended daily allowance (RDA). This treatment was able to lower the homocysteine level significantly by $17-50 \%$. Maximal effects may be seen after 4 to 6 weeks of therapy. ${ }^{7}$ Therefore, treatment of hyperhomocysteinemia should be approached on the basis of its etiology. ${ }^{6}$

\section{RELATIONSHIP BETWEEN VITAMIN $B_{6}, B_{12}$, AND FOLATE DEFICIENCIES AND HYPER- HOMOCYSTEINEMIA}

\section{Relationship of vitamin $B_{6}$ deficiency and hyper- homocysteinemia}

Park and Linkswiler ${ }^{18}$ reported that urinary homocysteine excretion increased considerably when six male volunteers consumed a diet depleted of vitamin $B_{6}$.

In case of vitamin $\mathrm{B}_{6}$ deficiency or a heterozygous cystathionine $\beta$-synthase defect, homocysteine transsulfuration is inhibited by the deficiency, but remethylation continues unimpeded. Therefore, only one pathway of homocysteine metabolism is impaired and no significant elevation in plasma homocysteine concentration is observed under fasting condition. Under condition of a methionine load, however, significant increases in the syntheses of both SAM and homocysteine will occur.

The resulting hyperhomocysteinemia is the result of three factors: (1) the reduction in the capacity of transsulfuration due to vitamin $B_{6}$ deficiency or enzyme defect, (2) the increased load of homocysteine that must be metabolized, and (3) the inhibition of methylenetetrahydrofolate reductase by SAM, which causes the impairment of homocysteine remethylation. In this way, both pathways of homocysteine metabolism are blocked and hyperhomocysteinemia occur. ${ }^{5}$

\section{Relationship of vitamin $B_{12}$ deficiency and hyper- homocysteinemia}

Homocysteine is a very sensitive and specific indicator in diagnosing tissue deficiency of cobalamin. ${ }^{19}$
Conversely, cobalamin concentration alone is not a definitive marker of homocysteine level and can be misleading. ${ }^{4}$ This was shown on several investigations that revealed the elevation of total serum homocysteine in every vitamin $\mathrm{B}_{12}$ deficient patient. Thus, elevated homocysteine concentrations suggest tissue vitamin-deficiency, even though serum vitamin $B_{12}$ are within normal limits. ${ }^{4}$

Pancharuniti et al found that at vitamin $B_{12}$ concentration of $<225 \mathrm{pmol} / \mathrm{L}$, homocysteine concentration starts to elevate. ${ }^{20}$ Stabler et al reported that 77 of 78 subjects with vitamin $B_{12}$ deficiency had also hyperhomocysteinemia. ${ }^{4}$ Lindenbaum et al investigated 548 elderly (67-96 years old), and found that $40.5 \%$ of the subjects had cobalamine serum of $<$ $258 \mathrm{pmol} / \mathrm{L}$, and $5.7 \%$ of the subjects had elevated homocysteine level $(>21.3 \mu \mathrm{mol} / \mathrm{L}){ }^{21}$

\section{Relationship between folate deficiency and hyperhomocysteinemia}

Pancharuniti et al found that at folate concentration of $<12.5 \mathrm{nmol} / \mathrm{L}$, homocysteine concentration started to elevate. ${ }^{20}$ In the case of folate deficiency, homocysteine remethylation is inhibited by the deficiency, resulting in a decrease in SAM syntesis. The concentration of SAM is then too low to activate cystathionine $\beta$-synthase, and thus the capacity of homocysteine transsulfuration to catabolize homocysteine is significantly reduced. Because both pathways of homocysteine metabolism are impaired, homocysteinemia is observed even under fasting condition. Under methionine load, there is a significant increase in the syntesis of both SAM and homocysteine. The rise in tissue SAM concentration will activate cystathionine $\beta$-synthase and induce an acceleration of homocysteine catabolism. As the result, no significant change in plasma homocysteine concentration is observed after a methionine load. ${ }^{5}$

\section{PATOPHYSIOLOGY OF ATHEROSCLEROSIS DUE TO HYPERHOMOCYSTEINEMIA}

Atherosclerosis is a slowly progressive disease of muscular arteries, in which the inner layer becomes thickened by fatty deposits and fibrous tissue. Pathogenesis of atherosclerosis is not fully understood. Despite the obvious relationship between risk factors and the occurrence of atherosclerotic diseases, the pathophysiological mechanisms which 
lead to atherosclerosis have not been totaly elucidated. ${ }^{22}$ However, the response to injury hypothesis provides a good explanation for the pathogenesis of atherosclerosis. This hypothesis proposes that injury to the endothelium is the initiating event in atherogenesis. ${ }^{22-23}$

Homocysteine is a vasculotoxic and thrombogenic amino acid which has been associated with premature vascular disease. ${ }^{13}$ Sulfur containing amino acids are able to generate partialy reduced oxygen species such as $\mathrm{O}_{2}{ }^{-}, \mathrm{H}_{2} \mathrm{O}_{2}$, and $\mathrm{OH}$. Furthermore, they are able to initiate lipid peroxidation in the presence of transition metal ion such as $\mathrm{Cu}^{++}$and $\mathrm{Fe}^{+H}$. Therefore, sulfurcontaining amino acid has a potential role in the modification of lipoprotein to a form recognized by scavenger receptors. ${ }^{24}$ Thus, homocysteine is not only a predictor of the risk of cardiovascular disease, but it is a chemical mediator causing injury to the endothelium and endothelial dysfunction, that causes the disease. ${ }^{25}$

The endothelial dysfunction is characterized by increased trapping of lipoproteins in the artery, the appearance of specific adhesive glycoproteins and the attachment of monocytes on the surface of endothelial cells. Growth regulatory molecules and chemoattractants are released by activated endothelial cells. Monocytes migrate into the subendothelial space and form fatty streaks, the earliest visible signs of atherosclerosis. ${ }^{26}$ The susceptibility to lipid deposition depends not only upon plasma lipid concentration and plasma flow rate through the vessel wall, but also upon the degree of endothelium injury produced by homocysteine. ${ }^{27}$ Further, accumulation of lipids, proliferation of smooth muscle cells, and formation of connective tissue (elastic fiber, collagen, and proteoglycan) occur. ${ }^{22}$

\section{CONCLUSION}

Hyperhomocysteinemia is known as one of the risk factor for premature atherosclerotic vascular disease. Hyperhomocysteinemia is caused by the inhibition of one or both pathways due to genetic or nutritional problems. Hyperhomocysteinemia caused by nutritional problem can be avoided by ensuring an adequate vitamins $B$, especially $B_{6}, B_{12}$ and folate intake.

\section{Acknowledgement}

My great appreciation is directed to dr. Sri Sukmaniah MSc., Ketua Kekhususan Gizi Klinik FKUI, who supported and guided the accomplishment of this paper, to my husband for his love and kind attention, also to our children, Karin and Adri for their love and understanding.

\section{REFERENCES}

1. Pietrzik L, Bronstrup A. Homocysteine and cardiovascular diseases. J Clin Nutr 1996; 5: 157-60.

2. Ueland $P M$, Mansoor MA, Guttormsen $A B$, Muller $F$, Aukrust P, Refsum $\mathrm{H}$, et al. Reduced, oxidized and protein-bound forms of homocysteine and other aminothiols in plasma comprise the redox thiol status a possible element of the extracellular antioxidant defense system. J Nutr $1996 ; 126: 1281 S-4 S$.

3. Allen RH, Stabler SP, Savage DG, Lindenbaum J. Metabolic abnormalities in cobalamin (vitamin B-12) and folate deficiency. Faseb J 1993;7:1344-53.

4. Stabler SP, Lindenbaum J, Alen RH. The use of homocysteine and other metabolites in the specific diagnosis of vitamin B12 deficiency. J Nutr 1996; 126:1266S-72S.

5. Miller JW, Nadeau MR, Smith D, Selhub J. Vitamin B6 deficiency vs folate deficiency : comparison of responses to methionine loading in rats. Am J Clin Nutr 1994; 59:1033-9.

6. Kang SS. Treatment of hyperhomocyst(e)inemia: physiological basis. J Nutr 1996;126:1273S-80S.

7. Mayer EL, Jacobsen DW, Robinson K. Homocysteine and coronary atherosclerosis. JACC 1996; 27: 517-27.

8. Nygard $\mathrm{O}$, Nordrehaug JE, Refsum $\mathrm{H}$, Ueland PM, Farstad M, Vollset SE. Plasma homocysteine levels and mortality in patients with coronary artery disease. N Engl J Med 1997; 337:230-6.

9. Ubbink JB, Delport R, Vermaak WJH. Plasma homocysteine concentrations in population with a low coronary heart disease prevalence. J Nutr 1996; 126:1254S-7S.

10. Chauveau P, Bernadette C, Coude M. Hyperhomocysteinemia, a risk factor for atherosclerosis in chronic uremic patients. Kidney Int 1993; 43:72S-7S.

11. Ueland PM, Refsum H, Brattstrom L. Plasma homocysteine and cardiovascular disease. In: Francis RB Jr., editor. Atherosclerotic Cardiovascular Disease, Hemostasis and Endothelial Function. New York: Marcel Dekker; 1992. p.183-236.

12. Stabler SP, Marcell PD, Podell ER, Allen RH, Savage G, Lindenbaum $\mathrm{J}$. Elevation of total homocysteine in the serum of patients with cobalamin or folate deficiency detected by capillary gas chromatography-mass spectrometry. J Clin Invest 1988; 81:466-74.

13. Refsum H, Wesenberg F, Ueland PM. Plasma homocysteine in children with acute lymphoblastic leukemia: changes during a chemotherapeutic regimen including methotrexate. Cancer Res 1991; 51:828-35.

14. Ueland PM, Refsum H. Plasma homocysteine, a risk factor for vascular disease: plasma levels in health, disease and drug therapy. J Lab Clin Med 1989; 114:473501 . 
15. Herzlich BC. Plasma homocyst(e)ine, folate, vitamin B6 and coronary artery disease risk. Am Coll Nutr 1996; 15:109-10.

16. Ubbink JB, Vermaak WJH, van den Merwe A, Becker PJ, Delport R, Potgieter HC. Vitamin requirements for the treatment of hyperhomocysteinemia in humans. J Nutr 1994; 124:1927-33.

17. Brattstrom L. Vitamins as homocysteine-lowering agents. J Nutr 1996; 126: 1276S-80S.

18. Park YK, Linkswiler H. Effect of vitamin B6 depletion in adult man on the excretion of cystathionine and other methionine metabolites. J Nutr 1970; 100:110-6.

19. Alen LH, Casterline J. Vitamin B12 deficiency in elderly individuals: diagnosis and requirements. Am J Clin Nutr 1994; 60:12-4.

20. Pancharuniti N, Lewis CA, Sauberlich HE, Perkins LL, Go RCP, Alvarez JO. Plasma homocyst(e)ine, folate and vitamin B12 concentrations and risk for early-onset coronary artery disease. Am J Clin Nutr 1994; 59:940-8.
21. Lindenbaum J, Rosenberg IH, Wilson PWF, Stabler SP, Allen RH. Prevalence of cobalamin deficiency in the Framingham elderly population. Am J Clin Nutr 1994; 60:602-11.

22. Ross R. The pathogenesis of atherosclerosis-an update. $\mathrm{N}$ Engl J Med 1986; 8:488-500.

23. Ross R. The pathogenesis of atherosclerosis : a perspective for the 1990s. Nature 1993;362, 801-9

24. Heinecke JW, Rosen H, Suzuki LA, Chait A. The role of sulfur-containing amino acids in superoxide production and modification of low density lipoprotein by arterial smooth muscle cells. J Biol Chem 1987; 262:10098-103.

25. Rosenberg IH. Homocysteine, vitamins and arterial occlusive disease : An Overview. J Nutr 1996;126: 1235S-7S.

26. Fernandopulle R, Loscalzo J. Atherosclerosis. In : Lilly LS, editor. Pathophysiology of Heart Disease. Philadelphia: Lea and Febiger; 1993. p. 84-97.

27. McCully KS, Ragsdale BD. Production of arteriosclerosis by homocysteinemia. Am J Pathol 1970; 61:1-9. 